\title{
An opportunity missed in tourism-led regeneration: Sulukule
}

\author{
P. Ozden \\ Department of Public Administration, Istanbul University, Turkey
}

\begin{abstract}
Tourism-led regeneration is one of the most significant agenda items in Istanbul where lively and serious discussions on urban regeneration workings still continue to a great extent. Within the scope of such tourism-led urban regeneration efforts are the District of Fatih, the Neslişah and Hatice Sultan Quarters, known by the public under the name Sulukule, where mostly Romany citizens are living. It was designated as a "Redevelopment Area" in 2005. Applications started to be implemented without providing any applicable "participation models" for the involvement of the affected parties and brought along with them a lot of conceptual and theoretical discussions as well as urban strains. On the other hand, work related to events to be organized for the selection and designation of Istanbul as one of the European Capitals of Culture for 2010 is rapidly continuing.

This paper aims to expose the "hasty and fickle" approach that is going on now, and has been for some years in the public sector, ignoring the concept of "participation" and disregarding any reactions, leading to an essential missed opportunity that is very important for tourism-led regeneration and may even have a negative effect. It can result in losses for Istanbul, currently preparing for the organization of the events to be implemented on the occasion of selection and designation of Istanbul as one of the European Capitals of Culture for 2010, and there is an urgent need to investigate the problems likely to be experienced in the period ahead in respect of the displaced people, and to make suggestions in this respect.

Keywords: participation, displacement, tourism-led regeneration.
\end{abstract}




\section{Introduction}

Urban regeneration implementations, developed rapidly in Turkey and especially in Istanbul in the 2000s, were mainly transformed into urban renewal in 2005. Conditions for urban renewal in protected areas were determined as per law number 5366 issued in 2005 for Renovation, Protection, Cherishing and Use of Worn Historical and Cultural Immovable Properties. This law came into effect as a significant tool for urban renewal implementations in Turkey and was used especially in Istanbul to create "brand projects". Sulukule Urban Renewal Project is one of them. However, the project not only disregarded the participation of the society but also adopted goals that will cause displacement of the Romany society who have lived there for centuries. In this manner, the method adopted contradicts the real principles of urban renewal. After a brief enlightenment about the general characteristics of the Sulukule region, targets of the Sulukule Project and stages of implementation, this study will discuss its significance in terms of the process of Istanbul 2010, Cultural Capital of Europe, its potentials for sustainable tourism and the opportunities lost, and it will end with evaluations and proposals.

\section{Tourism-led regeneration}

\subsection{Conceptual expansion}

Tourism-led regeneration; a significant matter of research is used as a basic approach for development of local economies undergoing economic depression and having tourism potential and revival of the area. It should also be noted that tourism-led regeneration has a cultural dimension in general and that this dimension is a significant input to tourism-led regeneration. According to Nel and Binns [1], "effective marketing and reliance on tourism-led development can have a noteworthy impact on a local economy". In short, tourism-led regeneration relying on culture will create socio-cultural value and economy at the local scale and will provide a significant contribution to sustainability of the area. Shaw et al. [2] emphasize that tourism-led regeneration should add value to the area by using the existing ethnic and cultural identity themes in the process of regeneration, and introduce a different approach to the concept.

\subsection{Tourism-led regeneration and Sulukule}

The Historical Peninsula region, the historical core of Istanbul, has a very lively identity. It is one of the most significant opportunities for Istanbul with the values and potentials that it possesses (Özden and Turgut [3]). On the other hand, Sulukule, located in the Fatih district of the Historical Peninsula, has been one of the most significant cultural areas of Istanbul with the cultural and recreational components that it incorporates. Wynne [4], in supporting this opinion, describes a cultural quarter as being "a geographical area which contains the highest concentration of cultural and entertainment facilities in a city or town". As 
foreseen by scientific criterion, Sulukule is an area that is in need of regeneration. Urban deprivation, crime, social marginalization, physical dilapidation and decay have become the conventional lifestyle of the Romany citizens in the area bearing ethnic characteristics. These elements reveal that the conditions necessary for regeneration are present. Besides, if all these unfavorable features are laid aside, Sulukule, with its joyful and lively Romany culture and life style, musicality, family entertainment houses and the incomparable dance shows made in these houses, gives strong hints for tourismled regeneration growing on culture. In short, revival of Sulukule seems possible with the adoption of a strong, rational and sustainable tourism-led policy. At this point, the matter pointed out by Nels and Binns [1] is important for the Romany citizens of Sulukule. They emphasize the opinion that, "tourism-led development, while creating jobs, may well lead to members of the colored community remaining as low-income laborers, working on the construction and servicing of the homes of wealthy retired whites, second home owners or holiday makers".

A goal that can be inferred from this could be the contribution of the people living there, the development of the local economy in tourism-led regeneration in Sulukule and improvement of socio-economic conditions of Romany families. Tourism-led regeneration should not only target spatial regeneration or provide benefits to its users, it should also adopt an approach that will also improve the socioeconomic conditions of Romany citizens who are the real owners of the area. It can also be suggested that tourism-led regeneration may also provide a solution to the problem of social marginalization by strengthening the organic relations between residents of the area and touristic users and also between its residents and public authorities.

\section{Sulukule urban regeneration project}

\subsection{A traditional Romany neighborhood: Sulukule}

Sulukule, comprising Hatice Sultan and Neslişah Sultan neighborhoods in Istanbul, has been the living area of Roman communities with traditional and ethnic features for hundreds of years. Its physical structure has been formed with this ethnic culture. Sulukule is located in the Fatih district in the Historical Peninsula, the oldest settlement and cultural area of Istanbul. The Hatice Sultan and Neslişah Sultan neighborhoods constituting the Sulukule region have on one side been undergoing a process of physical dilapidation for many years and also deal with social problems. The area where urban deprivation and social deprivation is at maximum levels, with high crime ratio and minimum living standards, has been neglected by local government to-date and has been abandoned to its own fate. Sulukule, with its population keeping alive the traditional Roman culture that it incorporates from the past until the present day, pursues a mission that serves the entertainment sector in Istanbul. It can be concluded that this area, which is one of the most recognized entertainment centers of Istanbul, has become a "brand" in this regard. Sulukule, even having a significant place in the introductory booklets about Istanbul, has provided 
contributions to tourism at a local scale with entertainment houses operated by Romany families. In this regard, a culture of family entertainment houses similar to the flamenco nights organized in Barcelona is in question. The area has a kind of "patina" formed with crime, urban deprivation, marginalization, physical dilapidation and general wear, the Romany culture and existence of many entertainment houses coexisting. The culture and tourism constituting this patina are factors that create basic values for this region.

\subsection{Project area}

The Sulukule Urban Renewal Project covers the Haticesultan and Neslişah neighborhoods just next to the historical city walls. The project implemented jointly by the Fatih Municipality, the Metropolitan Municipality and Mass Housing Authority (TOKI) started in September 2005. The project aims at the renewal of these two neighborhoods located in the city walls with buildings and infrastructure compatible with the historical urban texture, the urban and architectural heritage of the Historical Peninsula Official website of Fatih Municipality [5].

Household-based surveys were conducted in the project area, and the results of the survey revealed a profile of $31 \%$ illiterates, $34 \%$ primary school graduates, $5 \%$ junior high school graduates, $4 \%$ high school graduates. It was determined that nobody worked in $17 \%$ of families, children worked in $13 \%$ and women worked in $8 \% .77 \%$ of inhabitants of the area do not have a job that generates income and $64 \%$ are not within the scope of social security. The fact that $74 \%$ of the population wish to live there is a finding that is worth attention. $40 \%$ of inhabitants are home owners while $60 \%$ are either lessees or occupants. There are 620 right holders in the area. The net intensity of population is 1054 persons/hectares. Net intensity is organized as 870 persons/hectares in the project. Violence, poverty and narcotics are among the principal problems of the population living in the region. The survey conducted in the region revealed that the majority of the population lived in small rooms sharing a common garden with very unhealthy conditions. This method of use causes problems for the project in terms of holding rights and propriety.

\subsection{Goal, purpose and basic approaches of the project}

The aim, targets, policies and basic approaches of the project are stated in the following manner in the official website of Fatih Municipality: Aim of the Project, is determined as "implementation of healthy and comfortable rich spatial setup that will increase the quality of living of the existing users in the region reflecting the lifestyle and architecture of a period within the process of historical and spatial development of Istanbul, development of organization and programs that will provide improvements for economic and social aspects". Articles on the website cover the following areas:

- transforming the settlements that are not harmonious with the unique texture of the Historical Peninsula and making them conform to its identity and character; 
- description of functions for the planning are as a whole that conform to the historical features of the district of Fatih;

- protection of essential cultural and architectural values of the Sulukule region;

- revival of lost monumental pieces and significant civil architectural examples identified with the historical and cultural identity of the region with their original contours and templates and their contribution to the historical texture;

- connection of historical locations to each other with pedestrian axes and emphasizing the identity of pedestrians;

- creation of conditions that will prevent alienation of users from the environment and from each other;

- provision of participation of the population during the process of planning to the extent possible, taking into consideration proposals and requests;

- provision of participation to planning;

- getting opinions and proposals of NGOs, institutions and organizations concerned in the process of planning;

- provision of tourism functions that will provide cultural communication in the region;

- inclusion of income generating activities in the project;

- provision of sustainability by protection and development of already existing socio-cultural functions of the region;

- elimination of reasons for establishment of physical and economic dilapidation regions as a consequence of analytical researches to be conducted and replacement of existing structures with functions and structures that conform to the characteristics of the region;

- coming up with spatial strategies that will increase the quality of living in the region;

- making the necessary spatial arrangements in phases and development of necessary institutional, administrative and financial means in addition to increasing the level of consciousness to provide sustainability;

- increasing the attractiveness of the region with different functions to be developed for the region;

- provision of sustainability in the city walls by functional and spatial protection;

- taking into account the fact that planning does not only comprise of physical planning and that social, cultural, economic, legal and administrative dimensions should also be taken into consideration;

- implementation of a planning process with participation and support of the population and nongovernmental organizations.

When Basic Approaches were reviewed, the following were noted:

- a perspective aiming at the protection and development of the sociocultural identity of the environment and characteristics of the neighborhood inside the walls; 
- creation of functional and spatial solutions;

- elimination of components not compatible with the environmental identity;

- $\quad$ protection of existing construction sections and row houses in the new approach;

- $\quad$ establishment of a spatial setup of medium intensity with structures comprising of few floors (2-4 floors);

- intensification of spatial abundance with material diversity;

- designing accommodation and trade-culture facilities within spatial setup that will strengthen the urban features and outdoor living;

- $\quad$ strengthening the socio-cultural identity was observed.

It may be concluded that the project has a favorable vision when the above mentioned aim, target, policy and basic approaches are considered. However, it is understood that the statements cited above, which are theoretically correct, could not be implemented in real life. The project introduced as a social project followed a process, which was very close to participation and residents of the area were not informed in a correct manner. Although the project has targets such as income generating activities and tourism functions, tools and models that could implement these targets were not put forward. It was decided that $60 \%$ of the lessees and the majority of property owners for whom living in the area after the project has become impossible, be sent to the region of Taşoluk, which is quite far from the project area. Taşoluk displays different characteristics in terms of socio-cultural profile and is quite far away from the project region and this displacement led to a high level of discontent both for the users of the area, who do not know any other life outside Sulukule and have been isolated from the society due to marginalization, and also for the population already living in Taşoluk who do not want to live together with the people that will come from Sulukule. Similarly, the decision for lessees and/or persons who live in the region but cannot claim any rights to be sent by the Mass Housing Authority to the social residential areas in any part of the European side of Istanbul is not compatible with the approach of tourism-led regeneration of aiming to add value to the area by keeping such an ethnic culture together. Today, the concepts of local culture and local identity, and hence basic principles of tourism-led regeneration, are neglected in Sulukule as in other regeneration projects implemented by public administrations in almost all regions of Istanbul.

\section{Sulukule urban regeneration project: an opportunity missed for sustainable tourism and Istanbul 2010 European capital of culture}

\subsection{European capital of culture and Istanbul}

Cultural policies and planning are used as tools of urban regeneration in West European cities (Garcia [6]). Components such as cultural diversity, respect for common and shared values, and protection and improvement of human rights are 
included in these tools. The following expression is included in the report issued by Commission of the European Communities on 10 May 2007 in Brussels [6]:

"World-wide, cultural diversity and intercultural dialog have become major challenges for a global order based on peace, mutual understanding and respect for shared values, such as the protection and promotion of human rights and the protection of languages. In this respect the entry in to force of the UNESCO Convention on the protection and promotion diversity of cultural expressions on 18 March 2007 is to be seen as a fundamental step, to which the EU has greatly contributed".

The European Cities of Culture, the bases of which were laid in 1985 was renamed The European Capital of Culture in 1999. On 11 March 2006, Essen in Germany, Pécs in Hungary and Istanbul in Turkey were selected as European Capitals of Culture for 2010 by the EU Council. Since 1985, more than 30 cities have been designated European Capitals of Culture. The following expression is included within the scope of "Social Aims and Objectives"; one of the fundamental headings of the report prepared by Commission of the European Communities [7]:

"Although a number of cities have approached their programs from the perspective of cultural inclusion, it is not recognized as a distinct concern or area of practice. As a result the approach continues to be marginalized, and unlikely to fulfill its potential. Social objectives are becoming increasingly important in the thinking of ECOC'.

The EU Council of Ministers accepted in 2006 the application made for Istanbul to be the European Capital of Culture in 2010. Then the Law about Istanbul 2010 European Capital of Culture came into validity in 2007 with the purpose of establishment of the Istanbul 2010 European Capital of Culture Agency in order to prepare Istanbul as a European Capital of Culture for 2010, to plan and manage the activities to be conducted in 2010, and to provide coordination between public institutions and civil institutions and organizations. Duties of the Executive Committee operating within the structure of the agency may be summarized as:

- planning all exhibitions, concerts, show and tourism activities with cultural and social content that will take place within the scope of the project:

- $\quad$ to determine communication and promotion strategies and to follow up the activities conducted in relation to them, and to make recommendations to the institutions and organizations concerned for the establishment of urban transformation policies;

- to provide coordination between public institutions, chambers of commerce, NGOs and volunteer participants;

- to recommend projects for maintenance, repair and restoration of immovable cultural assets;

- to coordinate the promotion activities of the project in the country and to implement them abroad; 
- to establish connections with programs of other cities designated as European Capitals of Culture for the same year;

- $\quad$ to adopt resolutions for use of immovable properties;

- to conduct all kinds of purchasing, sales and leasing transactions related with the project;

- $\quad$ to propose locations where activities will be conducted;

- $\quad$ to make recommendations to institutions concerned about establishment of new locations for culture and arts.

Many of the European Capitals of Culture (ECOC) host European Cultural Month to increase the European or international profile of the city and for the city to catch attention as a capital of culture. The programs organized within this scope are generally implemented in close cooperation with cultural institutions and within the framework of national cultural activities. These activities are budgeted in certain ratios by the European Union. Nicosia, St. Petersburg, Ljubljana, Linz, Plovdiv, Basel, Riga, Krakow, Graz, Budapest, Amsterdam, Glasgow and other ECOC's organized hundreds of activities within this scope such as theater, music and dance shows, concerts, exhibitions, and festivals. Cultural tourism is the common denominator of these activities. For instance, it was emphasized that distinctive increases were noted in the number of tourists/visitors attending "performing arts" events and visiting museums, galleries, and historical buildings under the heading of "Continued Tourism Development" with regard to the effects of activities conducted in Glasgow ECOC [8].

Within this framework, the Agency undertook a significant mission to carry out the various renewal and regeneration projects proposed in Istanbul for 2010. However, the implementation projects thus far reveal that the Agency lacks efforts to realize this.

\subsection{A missed opportunity within the process of Istanbul 2010 capital of culture: Sulukule}

Evans [9] notes that increasing attractive areas would facilitate culture and tourism-led revival strategies and he emphasizes that assessment of 2010 from the perspective of tourism is mandatory for Istanbul and that methods should be found to attract more tourists in 2010.

Duties of the 2010 European Capital of Culture Agency, such as coming up with proposals for urban regeneration, maintenance, repair and restoration, and implementing the promotion activities of the project, is highly significant for Sulukule, constituting the subject matter of this study. While culture and tourism-led regeneration within the process of Istanbul 2010 European Capital of Culture should be considered as a basic target for Sulukule, it is observed that an approach wholly independent from this process is adopted.

It should also be noted that this approach contradicts the international agreements that Turkey is a party of. For instance, the "Treaty of Preservation of Intangible Cultural Heritage" signed by UNESCO in 2003, of which Turkey also became a party on 21 January 2006 expresses that "communities, especially local 
communities, groups and individuals under certain conditions play a significant role for generation, protection, maintenance and reconstitution of intangible cultural heritage and hence enrich cultural diversity and human creativity". The Treaty describes "intangible cultural heritage" as "Applications described by communities, groups and sometimes by individuals as part of their cultural heritage under certain conditions, plays, expressions, information, skills, tools and devices and cultural locations related with them". Protection of intangible cultural heritage, respecting intangible cultural heritage of communities, groups and individuals, increasing local, national and international sensitivity about importance of intangible cultural heritage, to provide mutual appreciation and to provide international cooperation and assistance are among goals of the Treaty. Similarly, Article 31 of the European Social Condition Treaty, about protection and restriction of democratic rights and freedoms, signed by Turkey in 1961, designates a direction quite the opposite of existing implementations from the perspective of intervention on rights.

As mentioned before, Sulukule is one of the oldest entertainment centers of Istanbul and it is a traditional living area of an ethnic society. The urban renewal project currently implemented in the area has not adopted an approach that takes these concepts into consideration. However, valuation of the Sulukule project within the scope of Istanbul 2010 European Capital of Culture would not only be an opportunity, it would also be one of the most suitable areas of Istanbul in terms of the duties to be undertaken by the Agency within the scope of urban renewal projects referred to above. In this sense, treating the area as a test case example by the Agency with the support and use of EU funds and transforming it into a center of attraction, as in other European Capitals of Culture in the past, seems beneficial. This approach is significant both for improving living standards of residents of Sulukule and for contributing to holistic regeneration of the city. Notwithstanding the foregoing, some NGOs reacted more sensitively that the local government in this respect and applied for EU funds for the Sulukule Neighborhood Development Project.

The following results are achieved when a simple SWOT (Strengths, Weaknesses, Opportunities and Threats) analysis is made for Sulukule within this framework:

Strengths: A traditional ethnic Romany culture is common in the area. Entertainment Houses operated by families, where they also live, attract attention of tourists to a large extent. In this regard, a brand value exists. Approximately $40 \%$ residents are property owners. Lessees also belong to the same social group. Existence of a homogenous and customary life style where many families live together in one backyard give significant clues to the dominant culture of living in the area. The area has a patina created by years of poverty, social marginalization, and physical wear and tear. There are 5 monuments, and 22 registered structures, 17 of which are examples of civil architecture. As the Law about Istanbul 2010 European Capital of Culture became valid in 2007, the tools and methods of implementation were determined, and the European Capital of Culture Agency was appointed as the responsible party. International Treaties constitute a strong legal basis for defining the intangible cultural heritage and 
protection of social rights. Almost all residents living in the area play one or more instruments and dance as a part of the Romany culture. Their inborn abilities are among the strongest parts of the area. An organized NGO structuring exists in the area. Press releases and public announcements of the platform formed by trade associations and academics, joining forces against the neighborhood foundation in the area and implementations keeps the area strong against local and central governments. The fact that some NGOs claimed EU funds with the Development Project of the Sulukule Neighborhood within the process of 2010 is a strong point.

Weaknesses: Physical wear and dilapidation is at maximum levels in the area. Similarly, the ratio of urban deprivation is also very high. Quite high ratios of snatch and run robberies, the trade of narcotics, and prostitution bring along problems of social marginalization and inability to integrate with the society. Income of one fourth of residents in the area is less that $300 \mathrm{TRY}$, while half of them earn less than 500 TRY. The facts that $77 \%$ of inhabitants do not have an income generating job and that $64 \%$ lack social security are among the weakest points of the area. The level of education is very low. More than $30 \%$ of residents are illiterate. The fact that the interest of the local government for development scenarios directed at the process of 2010 is less than NGOs is another weakness for implementation of the project. The social based projects pursued by NGOs also have weaknesses, as they did not cooperate with trade associations, hence dimensions of planning and design are missing.

Opportunities: Istanbul 2010 European Capital of Culture is a significant opportunity for Sulukule. Inclusion of the project in the scope of urban renewal is important. Articles of international treaties with foresight to revive the culture of living in these areas constitute a significant opportunity. Traditional-artistic potentials and tendencies of residents in the area provide opportunities to adopt a culture and tourism-led approach to the area.

Threats: Not taking international treaties into consideration threatens the sustainability of the area. The approach of the urban renewal project implemented in the area excluding and decreasing the social structure is a great threat. The process of ennobling, which is possible to occur based on the project, will also lead to displacement of persons planned to stay in the area. Polarization between Romany citizens planned to move to Taşoluk or to any social project area on the European side, and other residents not wishing to live with them, will make social decomposition even more distinctive and social tension will arise.

\section{Conclusion and assessment}

Conclusions for the area can briefly be cited as follows: Sulukule, with its nonmaterial cultural heritage has the potential of being a cultural center of attraction within the process of Istanbul 2010 European Capital of Culture, and this potential should be assessed in the most rational manner together with the brand value. Tourism-led regeneration in Sulukule should be supported with culture and not only the location but also the socio-economic and cultural conditions of residents of the area should be improved. Improvements should be 
made in the order of social relations and quality of living as a consequence of the development of the handicraft skills of users, their contribution to production by vocational activities, creation of opportunities for development and presentation of their music activities. Right owner should not only mean property owners. The Romany lessees there for many years should also be considered as owners of the area. The funds of the European Union should be channeled to Sulukule within the scope of 2010, and Istanbul should use the mission involved in being Capital of Culture to embrace traditional Romany Dance and Festivals, music ateliers and Romany Feasts. The European Capital of Culture Agency, based on authority vested by law should be the chief executor of the activities and should cooperate with local governments, universities, local and national NGOs and trade associations. The existing patina in the area should not be destroyed; but improvements foreseen in physical living conditions should be made with small touches and interventions. The colorful, lively and irregular texture of Sulukule, preserving its identity from the past until the present should be protected to the greatest extent possible. Physical conditions foreseen by tourism should be provided, improvements within the scope of contemporary physical conditions should be made in these areas as exampled in the enterprises where Flamenco nights are organized in Barcelona, they should be transformed into areas recorded, inspected and controlled by local governments.

\section{References}

[1] Nel E., Binns T., Place Marketing, Tourism Promotion and Community Based Local Economic Development in Post-Apartheid South Africa: The Case of Still Bay - The Bay of Sleeping Beauty, Urban Affairs Review 2002, 38, 184-208

[2] Shaw S, Bagwell S, and Karmowska J., Ethnoscapes as Spectacle: Reimaging Multicultural Districts as New Destinations for Leisure and Tourism Consumption, Urban Studies, September 2004, Vol. 41, No. 10, 1983-2000

[3] Özden P, Turgut S., Towards a Sustainable and Tourism-Led Urban Regeneration Objective: Eminonu Historical City Core, Sustainable Development and Planning II, Vol. 1, eds: Kungolos A.G., Brebbia C.A., Beriatos E., WIT Press, Southampton, Boston, s. 171-180

[4] ed: Wynne D., The Culture Industry: The Arts in Urban Regeneration, Avebury, Aldershot, 1992, UK

[5] Official Website of Fatih Municipality

[6] García, B., Cultural Policy in European Cities: Lessons from Experience, Prospects for the Future in: Special edition on Cultural Policy and Regeneration, Local Economy 2004, Vol 19, N. 4, 312-326

[7] Commission of the European Communities, "Communication From the Commission to the European Parliament, the Council, The European Economic and Social Committee and the Committee of Regions" on a European Agenda For Culture in a Globalizing World, 10 May 2007, Brussels 
[8] European Cities and Capitals of Culture, Study Prepared for the European Commission, Part 1, PALMER / RAE Associates, 2004, Brussels

[9] Evans G., Panel Speech, Beyoğlu'nu Yeniden Düşünmek Ve Düşlemek-1" (Rethinking and Dreaming Beyoğlu - 1", Kültür Ve Turizm Eksenli Yeniden Canlandırma Stratejileri Paneli, (Culture and Tourism Led Revival Strategies Panel) 2007, Istanbul 